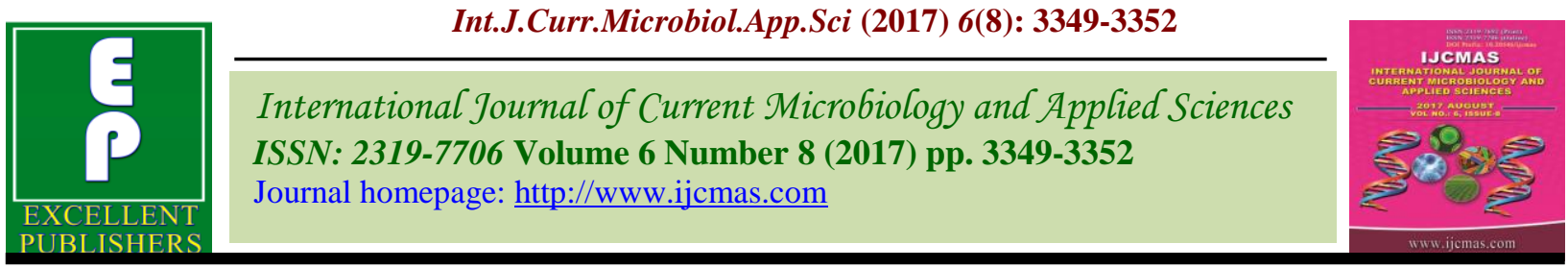

Case Study

https://doi.org/10.20546/ijcmas.2017.608.399

\title{
Unilateral Horn Cancer in Cow and its Surgical Management- A Case Report
}

\author{
K. Jagan Mohan Reddy*, V. Gireesh Kumar, S. Ganesh and K.B.P. Raghavender \\ Department of Veterinary Surgery and Radiology, College of Veterinary Science, \\ Rajendranagar, Hyderabad, PVNR Telangana Veterinary University -500030, India \\ *Corresponding author
}

A B S T R A C T

\begin{tabular}{|l|}
\hline K e y w o r d s \\
Cow, Horn \\
cancer, \\
Amputation, \\
Squamous cell \\
carcinoma. \\
\hline Article Info \\
\hline $\begin{array}{l}\text { Accepted: } \\
\text { 26 June 2017 } \\
\text { Available Online: } \\
\text { 10 August } 2017\end{array}$ \\
\hline
\end{tabular}

\section{Introduction}

Horn cancer is a common condition in bullocks in India affecting approximately one percent of population. (Giri et al., 2011 and Veena et al., 2011) Horn cancer is generally unilateral and is encountered in cattle in the age group of 5-10 years (Tyagi and Singh, 2006). The disease is associated with chronic irritation of horns at their base (Sastry, 2001). The most consistent clinical signs are frequent head shaking, tilting at the affected side, bending of affected horn and increase nasal discharge on the affected side in advance cases (Joshi et al., 2009). For treatment of horn cancer amputation of horn alone or along with chemotherapy using Vincristine were on reports (Udharwar et al., 2008 and Nicholas et al., 2011). The present case describes treatment of horn cancer in cow and its successful surgical management.

\section{History and symptoms}

A Non-descript cow of 6 years old was presented with previous history of broken horn, with growth at the base on left horn, foul smelling, blood discharge from the tumour growth. On clinical examination of affected horn, the cancerous growth was spongy, greyish white, pink cauliflower like tumour having rough and verrucous surface which was friable and bleed easily (Fig. 1). Based on the history and clinical examination, a tentatively diagnosed as horn cancer and amputation was performed

\section{Treatment}

The animal was restrained in standing position and the surgical site was prepared for aseptic surgery. Xylazine Hydrochloride (Xylaxin $^{\mathrm{R}}$, Indian Immunologicals, 
Hyderabad)@0.1 mg/ kg intramuscularly to sedate the animal. An amount of $10 \mathrm{ml} 2 \%$ Lignocaine hydrochloride (Xylocaine, Astra IDL Ltd Bangalore) was infiltrated in a fan pattern to desensitize the cornual nerve parallel to the frontal crest at its middle one third. After adequate analgesia dehorning was done by Flap method as suggested by Kumar (2005).

The incision was extended in an elliptical manner around the corium and the underlying tissues are separated at base of horn to raise full thickness dorsal and ventral skin flaps. Following skin incision the cornual artery were located on its ventral aspect and ligated by chromic catgut No.1 to prevent haemorrhages. The exposed horn was then dehorned closely to its base by using gigli wire saw. The remaining attachment to the bone was chiselled out with bone chisel.

The cavity was thoroughly curetted to get rid of neoplastic cells. To avoid any possibility of haemorrhage, gauze soaked in clotase was applied in the cavity for some time. The skin flaps were sutured by mattress suture pattern using silk No.2 and wound is covered with Tincture Benzoin seal to prevent haemorrhage. Post-operative treatment included administration of ceftriaxone (10 mg/kg intramuscularly), Meloxicam (0.2 $\mathrm{mg} / \mathrm{kg}$ intramuscularly) for 7 days, and chlorpheniramine maleate $(10 \mathrm{ml}$ intramuscularly) for 3 days.

Daily dressing of the suture line was performed with $0.1 \%$ Povidone iodine solution and applied Lorexane ointment for wound. The skin sutures were removed on $12^{\text {th }}$ post-operative day.

\section{Histopathology}

Histopathology examination of tissue revealed neoplastic epithelial cells extended into dermis forming focal islands, cords and trabeculae and showed variable degree of squamous differentiation. In addition epidermal hyperplasia, hyperkeratosis, fibrosis was also noticed. The amount of keratin seen as intracytoplasmic, eosnophilic fibrillar material showed distinct keratin "pearls".

The neoplastic cells forming focal islands were round with moderate amount of pale to basophilic cytoplasm. Mitotic figure were numerous. As suggestive of Squamous cell carcinoma (Fig. 2).

\section{Results and Discussion}

In the present case the recovery was uneventful and observed complete cure without any recurrence as reported by Giri et al., (2011), Jaiswal et al., (2014), Sharma and Singh (2014), Pitlawar et al., (2016) and Behera et al., (2016).

The specific chemotherapy including antineoplastic drugs could not be undertaken due to economic considerations (Veena et al., 2011) while, Kumar et al., (2013) used successfully vincristine sulphate @ $0.025 \mathrm{mg} / \mathrm{kg}$ intravenously thrice at interval of seven days for squamous cell carcinoma of horn after surgical excision.

Carcinoma of horn core in cattle is primarily squamous cell neoplasm.

Histological examination of cancerous tissue collected from middle region of horn core revealed typical keratinizing squamous cell carcinoma with characteristic epithelial pearls as observed by Giri et al., (2011), Jaiswal et al., (2014), Kumar et al., (2013) Pitlawar et al., (2016) and Behera et al., (2016). Early Diagnosis and treatment is essential for good prognosis. 
Fig.1 Cauliflower like growth in horn cancer

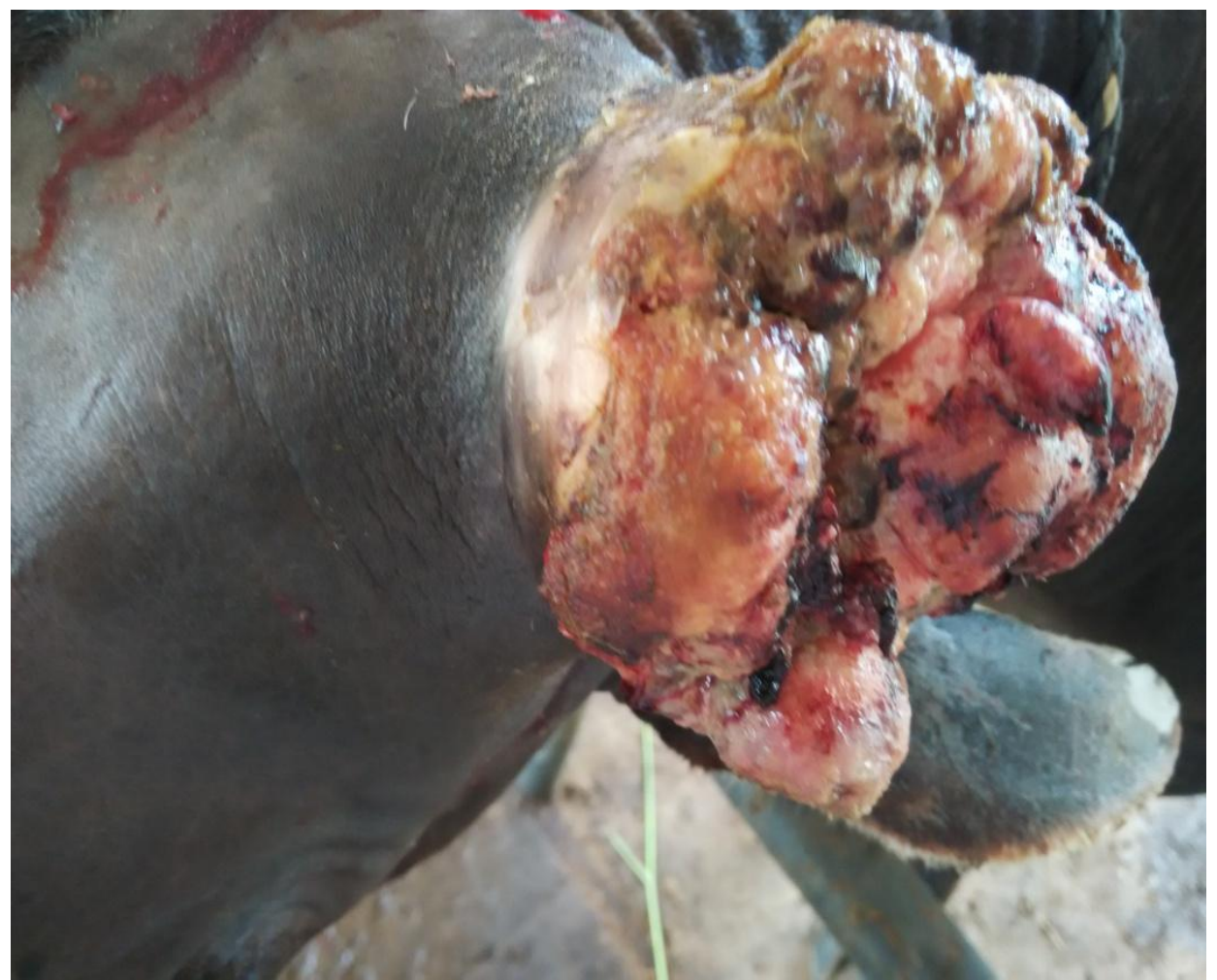

Fig.2 Squamous cell carcinoma of horn tumor showing distinct keratin Pearls.

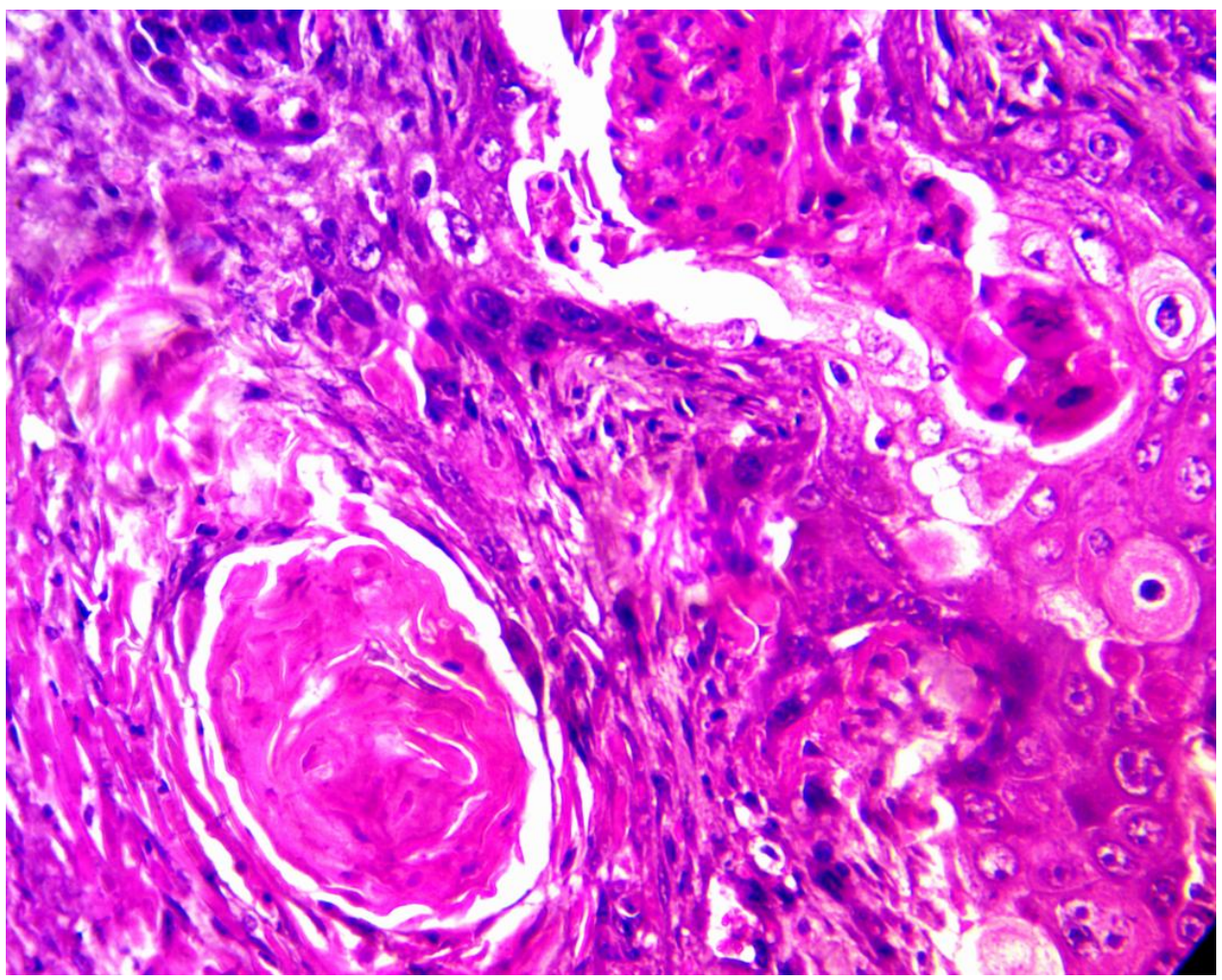


The cases of unilateral horn cancer in cattle can be successfully managed by surgical method if it is diagnosed in early stage.

\section{References}

Behera, S.S., Nayak, S and Behera, M. 2016. Surgical Management of Squamous Cell Carcinoma of Horn in a Cow. Intas Polivet Vol.17 (II): 241-242.

Giri, D.K., Kashyap, D.K., Dewangan, G., Tiwari, S.K., Ghosh, R.C. and Sinha, B. 2011. Squamous cell carcinoma of horn and its surgical management - a report of three cases. Int. J. Livest Res. 1:5558 .

Jaiswal, S., Singh, H.N., Kumar, S., and Jadon, N.S. 2014. Horn Cancer - A clinical insight into its Diagnosis and Management in 10 cattle. Intas Polivet Vol.15 (1): 3-6

Joshi, B.P., Soni, P.B., Ferar, D.T., Ghodasara, D.J. and Prajapati, K.S. 2009. Epidemiological and pathological aspects of horn cancer in cattle of Gujarat. Indian J. Field Vet. 5: 15-18.

Kumar, A., 2005. Veterinary Surgical Techniques, 2nd Edn, Vikas Publishing House Pvt. Ltd. New Delhi. pp. 217-19.

Kumar, V., Mathew, D.D., Kumar, N., and Arya, R.S., 2013. Horn cancer in Bovines and its Management. Intas
Polivet Vol. 14 (1): 56-57.

Nicholas, H.B and Mc Donald L.E 2001. Jones Veterinary Pharmacology and Therapeutics. $6^{\text {th }}$ Edn. Kaltani Printings, New Delhi.pp.874

Pitlawar, S.S., Gahlot, B.M., Akhare, S.B., Upadhye, S.V., and Jadhao, P.T. 2016. Surgical Management of Horn Affections - A Report of 2 Bullocks. Intas Polivet Vol.17 (II): 239-240

Sastry, G.A., 2001. Veterinary Pathology. 7th Edn, CBS Publisher and Distributors. New Delhi. pp. 205-49.

Sharma, N., and Singh, D. 2014. Unilateral Horn Cancer in a Bullock and its Management Intas Polivet Vol.15 (1): 7-8.

Tyagi, R.P.S., and Singh, J. 2006. Ruminant Surgery, 1st Edn, CBS Publisher and Distributors. New Delhi. pp. 415-16.

Udharwar, S.V., Aher, V.D., Yadav, G.U., Bhikane, A.U. and Dandge, B.P. 2008. Study on incidence, predisposing factors, symptomatology and treatment of horn cancer in bovine with special reference to surgery and chemotherapy. Vet. World 1: 7-9.

Veena, P., Kumar, R.V.S., Sankar, P., Dhanalakshmi, N. and Kokila, S. 2011. Squamous cell carcinoma of horn in a bullock- A case report. Ind. J. Anim Res. 45: 226-27

\section{How to cite this article:}

Jagan Mohan Reddy, K., V. Gireesh Kumar, S. Ganesh and Raghavender, K.B.P. 2017. Unilateral Horn Cancer in Cow and its Surgical Management- A Case Report. Int.J.Curr.Microbiol.App.Sci. 6(8): 3349-3352. doi: https://doi.org/10.20546/ijcmas.2017.608.399 